
$\checkmark$ Research Square
Preprints are preliminary reports that have not undergone peer review.
They should not be considered conclusive, used to inform clinical practice,
or referenced by the media as validated information.

\title{
Trade-off strategy of leaf functional traits of desert halophyte Lycium ruthenicum in the lower reaches of Heihe River, Northwest China: response to soil moisture and salinity
}

\author{
Shanjia Li ( $\sim$ lishanjia@lut.edu.cn ) \\ Lanzhou University of Technology \\ Wei Gou \\ Lanzhou University of technology \\ Hui Wang \\ Lanzhou University of Technology \\ Guoqiang Wu \\ Lanzhou University of Technology \\ Peixi Su \\ Northwest Institute of Eco-Environment and Resources
}

Research article

Keywords: Soil salinity · Soil water ·Desert halophyte · Leaf functional traits · Lycium ruthenicum

Posted Date: August 31st, 2019

DOI: https://doi.org/10.21203/rs.2.13833/v1

License: (c) (1) This work is licensed under a Creative Commons Attribution 4.0 International License. Read Full License 


\section{Abstract}

Abstract Background: Understanding salinity resistance and water utilization on shrub species is a challenge to the management and conservation of desert halophytes. Lycium ruthenicum Murr.with a significant soil and water conservation capacity, is one of the dominant shrubs and halophytes in the lower reaches of the Heihe River, Northwest China. In this paper, the effects of two depths (0-40 and 40-80 cm) of soil salinities and water contents on the leaf functional traits of eight L. ruthenicum communities in different distances from the main channel were studied. Fourteen leaf water physiological and ecological stoichiometric traits were investigated, linking with soil factors to explain desert plant trade-off strategies. Results: Specific leaf volume (SLV), specific leaf area (SLA), leaf thickness (LT), nitrogen (N), C:N, C:P could serve as good indicators of drought and saline resistance. Low N, specific leaf area (SLA) indicated that the plant was located at the slow investment-return axis of the species resource utilization. Low C:N, C:P showed that L. ruthenicum had a defensive life history strategy at drought and salinity areas. The RDA results showed that 0-40 and $40-80 \mathrm{~cm}$ soil properties respectively explained $93.45 \%$ and $99.96 \%$ leaf traits variation. Soil water contents, $\mathrm{HCO}-$ had extremely positive correlation $(\mathrm{P}<0.01)$ with leaf functional traits. Shallow soil water contents significantly affects $\mathrm{P}$, and deeper soil water contents significantly responds $\mathrm{C}$ and $\mathrm{N}$; shallow soil salinity significantly affected LT, C and $\mathrm{N}$ contents, whereas deeper soil salinity significantly affected $\mathrm{N}$ and SLV. Conclusions: L. ruthenicum had a foliar resource acquisition and resource conservation trade-off with a defensive life history strategy in the area of drought and salinity. This finding provides baseline information to facilitate the management and restoration of arid-saline desert ecosystem.

\section{Background}

Green leaves collect and store nutrients to become the basis of terrestrial ecosystem function. Through many people's discussion, functional traits are defined as measurable morphological, physiological, and phenological properties that are related to individual adaptation [1], these three classification traits accordingly include specific leaf area $(S L A)$, specific leaf volume $(S L V)$, photosynthetic rate, plant height, seed mass, etc. Plant functional traits are a hot topic in current ecological research, aiming to clearly link the phenotypes and physiological changes of individual plants to ecosystem processes and services [2-3] In the analysis of functional features that are easy to measure, two major trade-offs are immediately identified [4-5]. One of the trade-offs is explained by the fact that leaves with contrasting features promote rapid access to nutrients in fertile habitats while protecting resources in non-productive habitats [4]. The well-known "leaf economics spectrum" described trade-offs based on carbon, nutrients and discovered a trade-off between the quick and slow return of investments of nutrients and dry mass operating independently of biome, growth form or plant functional type [6]. Wherein leaves with higher nitrogen content tend to be lower leaf mass per unit area and short leaf life span, larger $\mathrm{A}_{\max }$ (the maximum rate of photosynthesis per unit of leaf mass) tends to be shorter leaf life span [6], other suites of related traits have been recognized that may indicate physical or physiological trade-offs [3]. Ecological stoichiometry is a comprehensive method for managing quality balances and provides a new perspective for understanding ecosystem process from the individual organism to the ecosystem level [7-9]. The key chemical components required for organisms, especially those structure and nutrients element: carbon $(C)$, nitrogen $(N)$ and phosphorus $(P)$. Gven the importance of understanding the elemental components and biogeochemical cycles coupled with phenotypic plasticity driven by component patterns found in terrestrial ecosystems, analyses of $\mathrm{C}: \mathrm{N}: \mathrm{P}$ ratios are increasing [10-14]. Previous studies showed that $C: N$ ratios were constrained by variation among different functional groups and scaled $N$ with respect to $C$ content in foliage $[11,13]$. In addition, the ratio of $\mathrm{C}: \mathrm{N}$ and $\mathrm{C}: \mathrm{P}$ indicates the ability of plants to assimilate $C$ while simultaneously absorbing $N$ and $P$. Comparatively, the ratio of $N$ : $P$ can reflect a dynamic balance between soil nutrients and plant nutrition demands $[10,15]$. Over the past decade, distribution patterns of $C, N$, and $P$ in plant leaves at global or regional scales as well as environmental factor relationship research has received widespread attention $[12,13,16]$. Recent studies tend to explain the temporal and spatial variability of plant functional traits under adverse (salinity, drought and frost stress) conditions [17-21].

Among many soil characteristics, salinity and moisture are important conditions affecting plant growth [22]. In arid environments, drought exerts a strongly selective pressure on morphological-chemical traits and plant life histories $[1,4,23]$. Salinity is one of the major environmental factors limiting plant growth, development, productivity and distribution pattern [24-26]. Excessive accumulation of salt in the soil imposes physiological limitations on plants, including osmotic stress, ion imbalance, oxidative stress and photosynthesis, thereby affecting plant growth [27-29]. This situation is exacerbated by the impact of human over-exploitation on land and the initial lack of water in the desert-oasis eco-interlaced zone in arid and semi-arid regions [30]. Severe water and salinity stress decreases a plant growth rate, leaf area, biomass accumulation [31]. However previous studies have suggested that appropriate saline conditions can enhance biological $C$ fixation of halophytes [32]. Another stoichiometrical research in an oasis-desert also indicated that soil conductivity was highly positively correlated with leaf $C, N$ contents [20]. But there was a significant negative correlation between leaf $P$ content and soil salt, conversely, a positive correlation was found between the ratios of leaf $C: P, N: P$ and soil salt [33]. The regression analyses for three functional groups along salinity gradients indicated that the salinity decreases leaf $C: N$, and increases $N: P$, but salinity was not the driver of leaf C:N:P stoichiometry in halophytes [24]. In summary, plants responses to stress have attracted much attention possibly due to the ecosystem degradation over the past decades. However, the adaptive strategy and tolerance of L.ruthenicum to drought and salinity stresses is not well understood.

Many studies have shown that $L$. ruthenicum is an important medicinal desert halophyte in the arid and saline land [34]. In addition to their nutritive values, $L$. ruthenicum can adapt to high salinity and drought through morphology adjustments in both carbon assimilation and metabolism, and can be a colony species with defensive functions on desert saline-alkali land [35]. It can prevent soil desertification and reduce the salinity and alkalinity through the special physiological characteristics of stress environment [36]. Therefore, it is of great significance to study the functional traits of $L$. ruthenicum in the desert salinealkali region where plant species diversity is lacking. In this paper, we measured the leaf water physiological and ecological stoichiometry traits of $L$. ruthenicum and different depths of soil salinity and water contents, selected an approximately $17 \mathrm{~km}$ long north-south transect of eight $L$. ruthenicum communities living under different salinity and moisture regimes from the lower reaches of the Heihe River of China. The objective of the present study was to explore: (1) Trade-off strategies between leaf functional traits under salinity and drought stress habitats; (2) What are the relationships between leaf functional traits and soil factors? ; And (3) Find major environmental factors that affect plant traits. 


\section{Methods}

\section{Study site}

The Heihe River is an inland river located in an extremely arid and fragile ecological environment in northwestern China. The desert ecosystem extends from the upstream to the downstream, with unique ecological structures and plant communities, dominated by shrubs [37]. The Ejina desert area is located in the lower reaches of the Heihe River Basin. According to the data of Ejinaqi Weather Station from 1957 to 2011 , the annual average temperature is $8.77^{\circ} \mathrm{C}$, the relative humidity is $33.9 \%$, the annual precipitation is $37.40 \mathrm{~mm}$, and the annual evaporation is $3390.26 \mathrm{~mm}$. In the environment with rare precipitation, the water supply in the Ejina desert area mainly comes from the Heihe River Basin, and the riverside vegetation is mainly assembled by shrubs and grasses. Shrubs are mainly Tamarix chinensis followed by Lycium ruthenicum, Nitraria tangutorum and Alhagi sparsifolia [38]. In Ejina desert, the plant species are poor, and the vegetation types are mainly dry and salt-tolerant desert plants, mainly distributed in the Heihe River and the lake plains of Ejina Banner. The soil types of the entire Heihe River series include brown calcium, desert calcium, meadows, salt and sand [37].

\section{Sampling protocol and community characteristics}

This study was conducted in early August 2017 within a $17 \mathrm{~km}$ long north-south transect in the lower reaches of the Heihe River Basin. Study area was flat and far from the village. We Selected 8 different communities of moisture and salinity conditions from the near to the far from the main river channel. Main distribution areas of plots and different plant habitat types were shown in Table 1 . Three quadrats $(5 \times 5 \mathrm{~m})$ were established within each selected community and their geographic information (latitude, longitude), desert types and plant community structure were investigated by GPS eXplorist 510 (Magellan, USA). Sunny side and fully expanded mature leaves $(n>30)$ were collected from 15 individuals of each $L$. ruthenicum communities, and all foliage sampled from 3 squares were combined into a mixed sample.

\section{Determination of leaf water physiological and stoichiometric traits}

The caliper with an accuracy of $0.02 \mathrm{~mm}$ was used to measure the thickness of the upper, middle and lower sides of the leaf ( $L T$, mm). The leaf area was determined by a combination of a scanner (EPSON DS-1610) and ImageJ software [39]. The specific leaf area (SLA, leaf area per unit dry mass), the specific leaf volume ( $S L V$, leaf volume per unit dry mass) was determined by a drainage method using a $10 \mathrm{~mL}$ cylinder, leaf dry matter content (LDMC, leaf dry mass per unit fresh mass), relative water content $(R W C$ \%). Total leaf water content $(T W C, \%)$, degree of the leaf succulence measured by saturation fresh weight minus dry weight divided by surface area $\left(S u c, \mathrm{~g} \cdot \mathrm{cm}^{-2}\right)$, leaf tissue density (the ratio of leaf dry weight to volume, $\left.L D, \mathrm{~g} \cdot \mathrm{cm}^{-3}\right)$. Since the leaves dehydrate after leaving the branches, the $L T, S L A$, and $S L V$ properties were all completed in the field, and then samples were taken back to the laboratory dried at $80{ }^{\circ} \mathrm{C}$ for $48 \mathrm{~h}$ to constant weight as well as other traits. Dried leaves were ground to a $0.15 \mathrm{~mm}$ powder using a sample pulverizer to measure the carbon $(C)$, nitrogen $(N)$ and phosphorus $(P)$ contents, and calculate the stoichiometric ratio. $C$ content was determined using the $\mathrm{K}_{2} \mathrm{Cr}_{2} \mathrm{O}_{7}-\mathrm{H}_{2} \mathrm{SO}_{4}$ external heating method in oil bath, $\mathrm{N}$ content was determined by the Semi-automatic Kjeldahl procedure, which involves digestion with concentrated $\mathrm{H}_{2} \mathrm{SO}_{4}$ followed by measurement of $\mathrm{NH}_{3}$ on an auto analyzer (Hanon K9840, Jinan, China), and leaf $P$ was digested by $\mathrm{H}_{2} \mathrm{SO}_{4}-\mathrm{H}_{2} \mathrm{O}_{2}$ and then measured by the molybdenum antimony method.

\section{Measurement of soil moisture, salinity and ion contents}

Soil was collected at 0-40 and $40-80 \mathrm{~cm}$ depths of 8 plant communities. We collected soil samples without rain within 7-10 days. The samples were first passed through a $2 \mathrm{~mm}$ screen to remove roots and other impurities, and then dried at $80{ }^{\circ} \mathrm{C}$ for moisture content analysis. Electrical conductivity (EC) measured using a DDS-307a portable conductivity meter (Leici Instrument, Shanghai, China). We have previously established a standard curve between the soil salinity and electrical conductivity of saline-alkaline soil in the study area as $y=217.73 x-22.723, R^{2}=0.994$, and the unit of soil salinity is $\mathrm{g} \cdot \mathrm{kg}^{-1}$. Soil samples were analyzed within 20 days of collection for carbonate $\left(\mathrm{CO}_{3}{ }^{2-}\right)$, bicarbonate $\left(\mathrm{HCO}_{3}{ }^{-}\right)$, chloride $\left(\mathrm{Cl}^{-}\right)$, sulfate $\left(\mathrm{SO}_{4}{ }^{2-}\right)$, sodium $\left(\mathrm{Na}^{+}\right)$, potassium $\left(\mathrm{K}^{+}\right)$, calcium $\left(\mathrm{Ca}^{2+}\right)$ and magnesium $\left(\mathrm{Mg}^{2+}\right)$ following methods described by the US Salinity Laboratory Staff [40].

\section{Statistical analysis}

All one-way analysis of variance (ANOVA) used by the SPSS 19.0 software. In order to distinguish the effects of different $L$. ruthenicum habitats on functional traits, tukey-HSD multiple range tests were performed at a significant level of $P \leq 0.05$. The Shapiro-Wilk test was performed to check for normality. CANOCO (version 4.5) was used for redundancy analysis to determine the effect of environmental gradients on plant functional traits. The Monte Carlo tests based on random permutations were conducted to test the significance of the Eigen values of the first canonical axis and all axes. Monte Carlo permutation test was used in each step and the significant difference level was 0.05 . Relationships between different plant functional traits were performed, using the Performance Analytics package of $\mathrm{R}$ statistical software [41].

\section{Results}

\section{Characteristic of the leaf functional traits in different communities of $L$. ruthenicum}

In this study, we measured 14 leaf functional traits (Table 2). Among them, leaf water physiology traits TWC, RWC, SLA, SLV, LT, LDMC, SUC, LD were 79.3588.37\%, 70.41-137.35\%, 0.005-0.008 $\mathrm{cm}^{2}-\mathrm{mg}^{-1}, 5.36-12.80 \mathrm{~cm}^{3} \mathrm{mg}^{-1}, 1.02-1.62 \mathrm{~mm}, 125.0-197.9 \mathrm{mg}=\mathrm{g}^{-1}, 0.80-1.38 \mathrm{~g}=\mathrm{cm}^{-2}, 0.08-0.19 \mathrm{~g}=\mathrm{cm}^{-3}$, respectively. Leaf ecological stoichiometry traits $C, N, P$ were $307.39-351.78,8.09-17.82,0.62-5.77 \mathrm{mg}^{-1}{ }^{-1}$, and $C: N, C: P$ and $N: P$ ratios were 20.28-37.97, 56.85-415.44, 2.7917.70 , respectively.

In eight different moisture and salinity environment sites (Table 1), we compared the differences between L. ruthenicum functional traits and found that larger

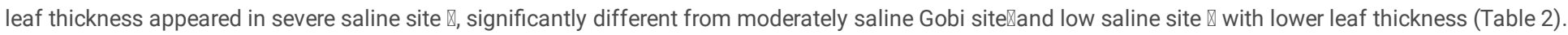

Page 3/11 


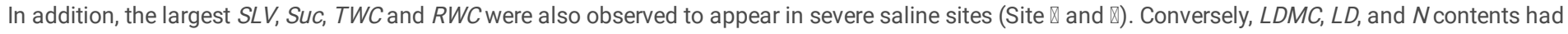
the lowest values in heavy saline areas. Leaf $N$ concentration was the least variable in different regions, but it still showed the effect of heavy saline on $L$. ruthenicum stress, and leaf $C$ content was significantly lower. Different degrees of drought stress (eight different soil moisture sites) had significant effects on leaf $P$ content (Fig.2), statistical analysis showed that the ratio of $N: P$ was more stable than $C: N$ and $C: P$ adaptation to drought-salt stress. Moreover, we found that there was no significant difference in the $S L A$ trait values between eight different habitats, meaning that intra-specific variation in $S L A$ at our finer ecological scale was minimal or non-existent.

\section{Correlation between leaf functional traits of $L$. ruthenicum in different habitats}

Correlation coefficient between 14 leaf traits of $L$. ruthenicum and significant different results showed (Fig.1) that $L T$ was significantly positively correlated with $\operatorname{Suc}(\mathrm{r}=0.58, P<0.05)$, on the contrary, extremely significantly negatively correlated with $C(\mathrm{r}=-0.81, P<0.001)$. $S L V$ was highly positively correlated with $S L A$ $(\mathrm{r}=0.74, P<0.01)$, both are significantly negatively $(\mathrm{r}=-0.95, P<0.001$ and $\mathrm{r}=-0.68, P<0.01$ respectively) correlated with $L D$ and significantly positively correlated with $\operatorname{TWC}(\mathrm{r}=0.81, P<0.001$ and $\mathrm{r}=0.57, P<0.05$ respectively). $L D M C$ was significantly positively correlated with $L D(\mathrm{r}=0.89, P<0.001)$, both of which were significantly negatively correlated with $T W C(\mathrm{r}=-0.95, P<0.001$ and $\mathrm{r}=-0.84, P<0.001$ respectively). Suc was significantly positively correlated with $T W C, R W C, P$ respectively (Fig.1), but it was significantly negatively correlated with $C(\mathrm{r}=-0.85, P<0.001)$. TWC was significantly positively correlated with $P$ contents $(\mathrm{r}=0.53$, $P<0.05)$, the latter with $N: P$ and $C: P$ were significantly negatively correlated $(\mathrm{r}=-0.76, \mathrm{r}=-0.86, P<0.001)$, and $N: P, C: P$ was significantly positively correlated $(\mathrm{r}=0.94, P<0.001) . R W C$ was highly negatively correlated with $N: P$ and $C: P(\mathrm{r}=-0.56, \mathrm{r}=-0.62, P<0.05)$.

\section{RDA restriction ordering of functional traits in soil water and salinity}

In view of the significant effect of salinity on plant growth, we were not only interested in the effects of total soil salinity on leaf functional traits, but also on the exploration of which salt ions mainly affect plant functional trait formation and variation. The RDA results showed that soil water contents and $\mathrm{HCO}_{3}$ had an extremely correlation with leaf functional traits, $0-40 \mathrm{~cm}$ (Fig.2a) and $40-80 \mathrm{~cm}$ soil properties (Fig.2b) respectively explained $93.45 \%$ and $99.96 \%$ leaf traits variation (the sum of the first two axes explained). Permutation tests for all canonical axes were significant $(P<0.01$, Table 3$)$. This suggested that models using these environmental factors can explain well the functional trait variation. In general, in the 0-40 cm soil layer, soil water contents significantly affected leaf $N: P, C: P, P$ contents and $R W C$ (Table 3, $P=0.002$, Fig.2a). Leaf $N: P$ and $C: P$ ratios are positively correlated with $0-40 \mathrm{~cm}$ soil water contents, while leaf $P$ contents and $R W C$ was negatively correlated with soil water contents. However, soil salinity significantly affected leaf $L T, C, N$ contents and $C$ : $N$ ratio, and positively with $L T, C: N$, negatively with leaf $C$ and $N$ contents. In $40-80 \mathrm{~cm}$ soil layer, $\mathrm{HCO}_{3}{ }^{-}$significantly influenced leaf functional traits (Table 3 ), soil water contents significantly reduced leaf $C$ and $N$ contents, but highly positively with $C: N$ (Fig.2b), while soil salinity only significantly reduced the leaf $N$ contents and highly positively with $C: N$, leaf morphological trait $S L V$. The spatial distribution of the eight community types may be driven by variation in soil chemical characteristics. Communities I, II and VII are close to each other due to their similar soil chemistry, as are VI and III, IV communities being close to each other. However, the V and VIII communities are located away from other communities, so their soil properties may differ from other locations. The Eigen values and total cumulative variance of RDA axes 1 and 2 are also high, indicating that species data are strongly correlated with measured environmental variables (Table 3).

\section{Discussion}

\section{Variations of $L$. ruthenicum leaf functional traits in the lower reaches of Heihe River}

In the long process of evolution, plants interact with the environment and gradually form adaptation strategies for internal physiology and external morphology to minimize the adverse effects of the environment. For example, leaf succulent, the so-called succulent plant refers to the proliferation of parenchyma cells in organs such as leaves and stems, the increase in the number of cells, the increase in volume, and the absorption and storage of large amounts of water, resulting in a significant increase in water content per unit weight or volume of tissue. These adapting plants to a phenomenon of poor environment and intra-plant traits vary with the environment, makes the plant can survive in a new environment [42]. This study showed that the desert halophyte $L$. ruthenicum was characterized by low leaf $S L A, L D M C, C, N$ and $N: P$ levels, high $L T$, Suc, P content and $C: N$ performance. SLA is one of the key leaf traits of plant carbon uptake strategy [43], it can reflect the distribution of plants and their adaptation to habitats [44]. $L D M C$ mainly reflects the ability of plants to retain nutrients [45]. In addition, $S L A$ and $L D M C$ are the best variables for classifying plant species on the plant resource utilization classification axis [6]. This paper showed that $L$. ruthenicum was a resource reservation species for its low $S L A, N$ content yet high $C: N$, this also indicated that $L$. ruthenicum is in "slow-return" end of the spectrum: Plants that invest in high LMA have a slower photosynthetic rate, but the leaf life is longer, so their slower income (carbon absorption) rate can be compensated by a longer income stream $[6,46]$. Furthermore, SLA and $L D M C$ are two important soil-fertility predictors as well as leaf $N$, $P$ nutrient contents and $N: P[15,47-49]$. The combination of these predictors indicates that soil fertility is lacking in the Ejina desert area in the lower reaches of Heihe River and the growth of $L$. ruthenicum is mainly restricted by $N$. Prior studies that have noted the importance of $C: N$ and $C: P$ ratios can effectively reflect the balance between competitive and defensive strategies [33]. When $N$ and $P$ contents were high, $C: N$ and $C: P$ ratios were comparatively low. Plants will apply competitive strategies at high photosynthetic rates. Conversely, when $C$ content was high, $C: N$ and $C: P$ ratios were high. This moment plants adopted a strong defensive strategy under low photosynthetic rates [50-51], The results of this study indicated that $L$. ruthenicum had a defensive strategy under desert saline habitats. Leaf thickness $(L T)$ is generally considered to be a very important leaf trait characteristic, which may be related to leaf life span, stress tolerance, and litter decomposition rate [52-53]. Osmond et al [54] found that plant leaves are thicker in nutrient-poor environments. This article $L T$ pattern was consistent with previous researches. In order to adapt to the poor environment, the succulent plants proliferate in a large number of parenchyma cells, such as leaves and stems. In eight different habitats, L. ruthenicum showed a significant succulence (Suc) used to store moisture in arid less rainfall environments of Ejina desert areas. Eight $L$. ruthenicum communities had higher $P$ content, may suggest that local minerals decompose faster meanwhile ensure that enough young leaves

Page $4 / 11$ 
are produced to reduce the persecution of salt toxic ions in the soil. The leaves of $L$. ruthenicum belong to succulent foliage, and the higher the water content (TWC) of the succulent plant, the stronger the degree of tolerance to water stress and the more drought-tolerant [55]. $S L V$ is an important leaf trait introduced according to the leaf characteristics of desert plants. $R W C$ reflects the resistance of plants to dehydration. The higher $R W C$ leads to stronger resistance to dehydration and leaves have higher osmotic adjustment function.

\section{Trade-off strategies among functional traits of $L$. ruthenicum}

The existence of a fundamental trade-off between the rapid acquisition and the efficient conservation of resources has been discussed in the ecological literature for more than forty years [56]. However, it is only over the course of the last two decades that the availability of large data sets has allowed for its precise quantification and for the identification of the trait syndromes that can be used to characterize trade-offs for a wide variety of plants [4,6,57]. Those strategies that have been proven include: Species with small SLA have thicker leaves or denser tissues [58], have been explained to allow maintenance of leaf function or delayed leaf death under very dry conditions [6]. Some fundamental relationships found in leaf economics spectrum work: A significantly positive correlation was found between $L T$ and Suc, which confirmed that succulent plant water conservation strategy[52]. While a significantly negative correlation was found between $L T$ and $C$ content, this is related to the thicker $L T$ causing a decrease in the specific leaf area and thus affecting carbon acquisition [59]. $S L A$ is a combination of leaf tissue density $(L D)$ and leaf thickness $(L T)$ : leaf tissue density is significantly positively correlated with leaf dry matter content $(L D M C)$, leading to the equation: $S L A=1 /(L D \times L T) \approx 1 /(L D M C \times L T)$ [59]. This paper did not show a significant relationship between $S L A$ and $L T$, but proved that $S L A$ has a strongly negative correlation with $\angle D M C$ and $L D$, the significantly negative correlation of $L T$ and $C$ as well as $S L A(S L V)$ and $L D(L D M C)$ indicated a trade-off between resource acquisition and resource conservation under drought and saline environment. $L D M C$ and $L D$ are positively correlated, both of which were significantly negatively correlated with TWC. Negative correlation of TWC, RWC and LDMC expressed as another trade-off between the intracellular water content and nutrient accumulation due to photosynthesis. Leaf water content is a useful indicator of plant water balance, Suc was significantly positively correlated with $T W C, R W C$ and $P$ content, but strongly negatively correlated with $C$. This study confirms that leaf succulence can improve the energy returns from leaf investment by replacing expensive $C$ structures with water [60].

\section{Does soil moisture and salinity affect plant functional traits?}

In contrast to significant trait correlation patterns, there were only a few significant changes in the leaf morphological traits and $C: N: P$ stoichiometry of desert halophytes with different salinity and moisture habitats. The distribution of salt in different soil layers might explain these results. In this paper, shallow soil layer $(0-40 \mathrm{~cm})$ water content significantly affected leaf $P$ content but not $C$ and $N$ contents, also significantly affected leaf $N: P, C: P$ because of higher leaf $P$ content, this result supports evidence from previous observations[61], the effect of shallow soil moisture on leaf stoichiometry may be interpreted as rich applicability of soil $N$, while $P$ nutrient element is unstable. In addition, shallow soil layer water content significantly affected the leaf $R W C$ trait at the negative direction, and shallow soil water significantly promoted the leaf $C: P$ ratio showed $L$. ruthenicum had a defensive life strategy. However, soil salinity significantly affected leaf $L T, C, N$ contents and $C: N$ ratio, positively with $L T, C: N$, negatively with leaf $C$ and $N$ contents. This may be a morphological and physiological evolutionary strategy for plants to cope with salt stress. In the deeper soil layer $(40-80 \mathrm{~cm}), \mathrm{HCO}_{3}{ }^{-}$significantly influenced leaf functional traits, deeper soil layer water contents significantly reduced leaf $C$ and $N$ contents, highly positively with $C: N$, but not obviously influenced leaf $P$ content and other functional traits, while soil salinity only significantly reduced leaf $N$ contents and highly positively with $C: N$ and leaf morphological trait $S L V$. Thus, the hydraulic properties required for plant safety at high salinity are at the expense of lower growth rates [62]. In general, salt stress causes the normal growth of plants to be inhibited to varying degrees, mainly because salt stress inhibits plant photosynthesis by reducing soil water potential and reducing leaf stomatal conductance [63-64]. Therefore, the fixed $C$ ability of the blade will also be reduced significant, this was consistent with the low leaf $C$ phenomenon in this study. Many studies have confirmed that under salt stress, especially the higher $\mathrm{Cl}^{-}$content in the soil will inhibit the plant's absorption of $\mathrm{NO}_{3}{ }^{-}$, so the $\mathrm{NO}_{3}{ }^{-}$ content in the leaves of the plants will decrease [65-66], from this point of view, the $N$ content of halophytes decreases as well as the $C$ content. However, some other studies have shown that the $N$ content of succulent plants becomes larger as the salinity increases [24], this controversy will require more research in the future to prove.

Salt stress limits the growth of halophytes through adverse effects on various physiological and biochemical processes. Conversely, halophytes shows a response to increased salinity by diversity growth [28]. Salinisation consists of an accumulation of water soluble salts in the soil that include the ions of $\mathrm{K}^{+}$, $\mathrm{Mg}^{2+}, \mathrm{Ca}^{2+}, \mathrm{Cl}^{-}, \mathrm{SO}_{4}{ }^{2-}, \mathrm{CO}_{3}{ }^{2-}, \mathrm{HCO}_{3}{ }^{-}$and $\mathrm{Na}^{+}$. We tried to analysis this process with salt ions of different depths of soil. The RDA results showed that $\mathrm{SWC}$, $\mathrm{HCO}_{3}{ }^{-}, \mathrm{Cl}^{-1}$ and $\mathrm{CO}_{3}{ }^{2-}$ can explain the variation of functional traits well. Surprisingly, $\mathrm{Na}^{+}$was not in this rank. Because the importance of $\mathrm{Cl}^{-}$and $\mathrm{Na}^{+}$has been mentioned in much salinity stress studies[67-69]. It was found that $\mathrm{Na}^{+}$is more effective than $\mathrm{K}^{+}$and $\mathrm{Cl}^{-}$in cell swelling, leaf succulence and shoot development[70]. According to our knowledge, the soluble salt in the lower reaches of the Heihe River Basin dominated by $\mathrm{Na}^{+}, \mathrm{HCO}_{3}{ }^{-}, \mathrm{SO}_{4}{ }^{2-}$ and $\mathrm{Ca}^{2+}[71]$, the above study may explain the results of our soil ion effects on functional traits.

\section{Conclusion}

This study found that the patterns of leaf functional traits in arid desert halophyte $L$. ruthenicum in arid and saline environments have a tendency of low leaf $S L A, \angle D M C, C, N$ and $N: P$ levels, but high $L T$, SUC, $P$ content and $C: N$ performance, and leaf average $N: P<14$. Our findings are as follows: (1) The ratio of leaf $N: P$ was more stable than $C: N$ and $C: P$ adaptation to drought-salt stress. There was no significant difference in average $S L A$ trait values between eight different habitats, indicating that intra-specific variation in $S L A$ at a finer ecological scale was minimal or non-existent. (2) Resource acquisition and resource conservation trade-off; (3) Shallow soil moisture significantly affects leaf $P$, and deep soil moisture significantly responds leaf $C$ and $N$; Shallow soil salinity significantly affected $L T, C$ and $N$ contents, whereas deep soil salinity significantly affected leaf $\mathrm{Nand} S L V$. $\mathrm{HCO}_{3}{ }^{-}$and soil water contents have significant effects on leaf functional traits. (4) Given that these remarkable features we recommend $L$. ruthenicum had a defensive life history strategy at drought and 
salinity areas. Although this paper proved to some extent the effect of soil water and salt on functional traits, however, other larger scale studies are needed to determine the drivers of functional characteristics.

\section{Abbreviations}

$L T$ : leaf thickness (mm); $S L A$ : specific leaf area $\left(\mathrm{cm}^{2} \cdot \mathrm{mg}^{-1}\right)$; $S L V$ : specific of leaf volume $\left(\mathrm{cm}^{3} \cdot \mathrm{g}^{-1}\right) ; L D M C$. leaf dry matter content (mg- $\left.\mathrm{g}^{-1}\right)$; SuC: leaaf Sucuulent $\left(\mathrm{g}=\mathrm{cm}^{-2}\right)$; $L D$. leaf tissue density $\left(\mathrm{g}=\mathrm{cm}^{-3}\right) ; T W C$. Total water content(\%); $R W C$. relative water content(\%); $C$. leaf carbon content(mg- $\left.\mathrm{g}^{-1}\right) ; N$ : leaf nitrogen content $\left(\mathrm{mg}=\mathrm{g}^{-1}\right)$; $P$ : leaf phosphrous content $\left(\mathrm{mg}^{-1} \mathrm{~g}^{-1}\right) ; N: P, C: N, C: P$. the ratios of $C, N$ and $P$.

\section{Declarations}

\section{Authors' contributions}

SJL conceived and designed the experiments, revised the first draft; WG analyzed the data and wrote draft; HW and WG performed experiments; GQW and PXS guided writing and participated in the survey. All authors read and approved the final manuscript.

\section{Author details}

${ }^{1}$ School of Life Science and Engineering, Lanzhou University of Technology, Lanzhou 730050, China; ${ }^{2}$ Key Laboratory of Land Surface Process and Climate Change in Cold and Arid Regions, Northwest Institute of Eco-Environment and Resources, Chinese Academy of Sciences, Lanzhou 730000, China.

\section{Acknowledgements}

We are grateful to ZQ Li, KB Li, YL, JZ Chen for their help with fieldwork, to RL Zhao with lab work, and to Dr. LY for identifying plant species.

\section{Availability of data and materials}

The data sets supporting the results are included within the article and additional file 1.

\section{Competing interests}

The authors declare that they have no competing interests.

\section{Funding}

This research was funded by National Natural Science Foundation of China grant number 41261013, Gansu Provincial Key Research and Development Program grant number 18YF1FA066, Lanzhou Science and Technology Development Program grant number 2017-4-94.

\section{Ethics approval and consent to participate}

There was no requirement to seek ethical approval to carry out the work described above.

\section{Consent for publication}

Not applicable.

\section{References}

1. Violle C, Navas ML, Vile D, Kazakou E, Fortunel C, Hummel I, Garnier E. Let the concept of trait be functional. Oikos. 2007;116:882-892.

2. Bernhardt-Römermann M, Römermann C, Nuske R, Parth A, Klotz S, Schmidt W, Stadler J. On the identification of the most suitable traits for plant functional trait analyses. Oikos. 2008;117:1533-1541.

3. Westoby M, Wright I J Land-plant ecology on the basis of functional traits. Trends Ecol Evol. 2006;21:261-268.

4. Díaz S, Hodgson JG, Thompson K, Cabido M. The plant traits that drive ecosystems: evidence from three continents. J Veg Sci. 2004;15:295-304.

5. Pierce S, Bottinelli A, Bassani I, Ceriani RM, Cerabolini BEL. How well do seed production traits correlate with leaf traits, whole-plant traits and plant ecological strategies?. Plant Ecol. 2014;215:1351-1359.

6. Wright IJ, Reich PB, et al . World-wide leaf economics spectrum. Nature. 2004;428:821-827.

7. Sterner RW, Elser JJ. Ecological stoichiometry: the biology of elements from molecules to the biosphere. 2002; Princeton University Press, Princeton.

8. Hessen DO, Ágren GI, Anderson TR, Elser JJ, de Ruiter PC. Carbon sequestration in ecosystems: the role of stoichiometry. 2004;85:1179-1192.

9. Ágren GI, Weih M. Plant stoichiometry at different scales: element concentration patterns reflect environment more than New Phytol. 2012;194:944-952.

10. Güsewell S. N:P ratios in terrestrial plants:variation and functional significance. New Phytol. 2004;164:243-266.

11. McGroddy ME, Daufresne T, Hedin LO. Scaling of C:N:P stoichiometry in forest worldwide: implications of terrestrial redfield-type ratios. Ecology.2004;85:2390-2401.

12. Reich PB, Oleksyn J. Global patterns of plant leaf N and P in relation to temperature and latitude. P Natl Acad Sci USA. 2004;101:11001-11006.

13. Han WX, Fang JY, Guo DL, Zhang Y. Leaf nitrogen and phosphorus stoichiometry across 753 terrestrial plant species in New Phytol. 2005;168:377-385.

Page 6/11 
14. He JS, Fang JY, Wang ZH, Guo DL, Flynn DF, Geng Z. Stoichiometry and large-scale patterns of leaf carbon and nitrogen in the grassland biomes of China. Oecologia1. 2006;49:115-122.

15. Koerselman W, Meuleman AFM. The vegetation N:P Ratio: a new tool to detect the nature of nutrient limitation. J Appl Ecol.1996;33:1441-1450.

16. He JS, Wang L, Flynn DFB, Wang XP, Ma WH, Fang JY. Leaf nitrogen: phosphorus stoichiometry across Chinese grassland biomes. Oecologia. 2008;155:301-310.

17. Xu GQ, Yan L, Hao X. Seasonal variation in plant hydraulic traits of two co-occurring desert shrubs, Tamarix ramosissima and Haloxylon ammodendron, with different rooting patterns. Ecol Res. 2011;26:1071-1080.

18. Zhang L, Zhang GW, Wang YH, Zhou ZG, Meng YL, Chen BL. Effect of soil salinity on physiological characteristics of functional leaves of cotton plants. J Plant Res. 2013;126:293-304.

19. Wang N, Gao J, Zhang SQ, Wang GX. Variations in leaf and root stoichiometry of nitraria tangutorum along aridity gradients in the Hexi Corridor, Northwest China. Contemp Probl Ecol. 2014;7:308-314.

20. Zhang K, Su YZ, Liu TN, Wang T. Leaf C:N:P stoichiometrical and morphological traits of Haloxylon ammodendron over plantation age sequences in an oasis-desert ecotone in North China. Ecol Res. 2016;31:449-457.

21. Bucher SF, Robert F, Buchner O, Neuner G, Rosbakh S, Leiterer M, Roemermann C. Temporal and spatial trade-offs between resistance and performance traits in herbaceous plant species. Environ Exp Bot. 2019; 157:187-196.

22. Arndt SK. Integrated research of plant functional traits is important for the understanding of ecosystem processes. Plant Soil. 2006;285:1-3.

23. Niu K, Zhang S, Zhao B, Du G. Linking grazing response of species abundance to functional traits in the Tibetan alpine meadow. Plant Soil. 2010;330:215223.

24. Wang LL, Zhao GX, Li M, Zhang MT, Zhang LF, Zhang XF, An LZ, Xu SJ. C:N:P stoichiometry and leaf traits of halophytes in an arid saline environment, Northwest China. Plos One. 2015;10:e0119935. https://doi.org/10.1371/journal.pone.0119935.

25. Li JY, Zhao CY, Li J, Yan YY, Yu B, Han M. Growth and leaf gas exchange in Populus euphratica across soil water and salinity gradients. Photosynthetica. 2013; 51:321-329.

26. Lu YW, Miao XL, Song QY, Peng SM, Duan BL. Morphological and ecophysiological plasticity in dioecious plant Populus tomentosa under drought and alkaline stresses. Photosynthetica.2018; 56:1353-1364.

27. Shabala S, Munns R. Salinity stress: physiological constraints and adaptive mechanisms. Plant Stress Physiology. 2012;https://doi.org/10.1079/9781845939953.0059.

28. Flowers TJ, Colmer TD. Salinity tolerance in halophytes. New Phytol.2008;179:945-963.

29. Munns R, Tester M. Mechanisms of salinity tolerance. Annu Rev Plant Biol. 2008; 59: 651-681.

30. Wang Y, Li Y. Land exploitation resulting in soil salinization in a desert-oasis ecotone. Catena.2013; 100:50-56 https://doi.org/10.1016/j.catena.2012.08.005.

31. Rodríguez P, Torrecillas A, Morales MA, Ortuno MF, Sánchez-Blancoa MJ. Effects of $\mathrm{NaCl}$ salinity and water stress on growth and leaf water relations of Asteriscus maritimus Environ Exp Bot. 2005;53:113-123.

32. Sun X, Gao Y, Wang D, Chen J, Zhang F, Zhou J, Yan X, Li Y. Stoichiometric variation of halophytes in response to changes in soil salinity. Plant Biology. 2017; 19:360-367.

33. Rong QQ, Liu JT, Cai YP, Lu ZH, Zhao ZZ, Yue WC, Xia JX. Leaf carbon, nitrogen and phosphorus stoichiometry of Tamarix chinensis in the Laizhou Bay coastal wetland,China. Ecol Eng. 2015; 76:57-65.

34. Zhao J, Xu F, Ji T, Li J. A New Spermidine from the Fruits of Lycium ruthenicum. Chem Nat Compd. 2014;50:880-883.

35. Wei Y, Xu X, Tao H, Wang P. Growth performance and physiological response in the halophyte Lycium barbarum grown at salt-affected soil. Ann Appl Biol. 2006;149:263-269.

36. Zheng J, Ding CX, Wang LS, Li GL, Shi JY, Li H, Wang HL, Suo YR. Anthocyanins composition and antioxidant activity of wild Lycium ruthenicum from Qinghai-Tibet Plateau. Food Chem.2011;126:859-865.

37. Li XR, Tan HJ, He MZ, Wang XP, Li XJ. Patterns of shrub species richness and abundance in relation to environmental factors on the Alxa Plateau: Prerequisites for conserving shrub diversity in extreme arid desert regions. Sci China Ser B. 2009;52:669-680.

38. Fu AH, Chen YN, Li WH. Water use strategies of the desert riparian forest plant community in the lower reaches of Heihe River Basin, China. Science China Earth Sciences. 2014;57:1293-1305.

39. Rasband WS. ImageJ. National Institutes of Health, Bethesda.1997-2016; https://imagej.nih.gov/ij/.

40. USSL Staff. Diagnosis and improvement of saline and alkali soils. USDA Handbook No 60. Washington DC, USA, 1954. p160.

41. Brian G, Peterson PC. PerformanceAnalytics: econometric tools for performance and risk analysis. 2018;R package version 1.5.2. https://CRAN.Rproject.org/package=PerformanceAnalytics.

42. Byars SG, Papst W, Hoffmann AA. Local adaptation and cogradient selection in the alpine plant, Poa hiemata, along a narrow altitudinal gradient. Evolution.2007; 61:2925-2941.

43. Wright IJ, Westoby M, Reich PB. Convergence towards higher leaf mass per area in dry and nutrient-poor habitats has different consequences for leaf life span. J Ecol. 2002; 90:534-543.

44. Burns KC. Patterns in specific leaf area and the structure of a temperate heath community. Divers Distrib.2004;10:105-112. 
45. Saura-Mas S, Lloret F. Leaf and shoot water content and leaf dry matter content of mediterranean woody species with different post-fire regenerative strategies. Ann Bot. 2007; 99:545-554.

46. Westoby M, Falster DS, Moles AT, Vesk PA, Wright IJ. Plant ecological strategies: some leading dimensions of variation between species. Annu Rev Ecol Syst. 2002;33:125-159.

47. Wilson PJ, Thompson K, Hodgson JG. Specific leaf area and leaf dry matter content as alternative predictors of plant strategies. New Phytol.1999; 143:155-162.

48. Kleyer M, Bekker RM, Knevel IC, et al. The LEDA Traitbase: a database of life-history traits of the Northwest European flora. J Ecol. 2008; 96:1266-1274.

49. Hodgson JG, Marti GM et al. Is leaf dry matter content a better predictor of soil fertility than specific leaf area?. Ann Bot. 2011; 108:1337-1345.

50. Poorter L, Bongers F. Leaf traits are good predictors of plant performance across 53 rain forest species. Ecology. 2006;87:1733-

51. Shipley B, Lechowicz MJ, Wright I, Reich PB. Fundamental trade-offs generating the worldwide leaf economics spectrum. 2006;87:535-541.

52. Morandeira NS, Kandus P. Plant functional types and trait values in the Paraná River floodplain: modelling their association with environmental features. Flora-Morphology Distribution Functional Ecology of Plants. 2016; 220:63-73.

53. Reich PB, Walters MB, Ellsworth DS. From tropics to tundra: global convergence in plant functioning. P Natl Acad Sci USA. 1997;94:13730-13734.

54. Osmond CB, Austin MP, Berry JA, Billings WD, Boyer JS, Dacey JWH, Nobel PS, Smith SD, Winner WE. Stress physiology and the distribution of plants. Bioscience. 1987; 37:38-48.

55. Marenco RA, Antezana-Vera SA, Nascimento HCS. Relationship between specific leaf area, leaf thickness, leaf water content and SPAD-502 readings in six Amazonian tree species. Photosynthetica. 2009; 47:184-190.

56. Reich PB, Cornelissen H. The world-wide 'fast-slow' plant economics spectrum: a traits manifesto. J Ecol. 2014; 102:275-301.

57. Grime JP. Evidence for the existence of three primary strategies in plants and its relevance to ecological and evolutionary theory. AM Nat. 1977; 111:11691194.

58. Hassiotou F, Renton M, Ludwig M, Evans JR. Photosynthesis at an extreme end of the leaf trait spectrum: how does it relate to high leaf dry mass per area and associated structural parameters?. J Exp Bot. 2010; 61:3015-3028.

59. Shipley B, Vu TT. Dry matter content as a measure of dry matter concentration in plants and their parts. New Phytol. 2002; 153:359-364.

60. Shipley B. Structured interspecific determinants of specific leaf area in 34 species of herbaceous angiosperms. Funct Ecol. 1995;9:312-319.

61. Zhang B, Gao XP, Li L, Lu Y, Shareef M, Huang CB, Liu GJ, Gui DW, Zeng FJ. Groundwater depth affects phosphorus but not carbon and nitrogen concentrations of a desert phreatophyte in Northwest China. Front Plant Sci. 2018; 9:338 https://doi.org/10.3389/fpls.2018.00338.

62. Nguyen HT, Stanton DE, Schmitz N, Farquhar GD, Ball MC. Growth responses of the mangrove Avicennia marina to salinity: development and function of shoot hydraulic systems require saline conditions. Ann Bot. 2015;115:397-407.

63. Dodd GL, Donovan LA. Water potential and ionic effects on germination and seedling growth of two cold desert shrubs. AM J Bot. 1999; 86:1146-1153.

64. Rahnama A, James RA, Poustini K, Munns R. Stomatal conductance as a screen for osmotic stress tolerance in durum wheat growing in saline soil. Funct Plant Biol. 2010;37:255-263.

65. Baki AE, Siefritz F, Man HM, Weiner H, Kaldenhoff R, Kaiser W. Nitrate reductase in Zea mays L. under salinity. Plant Cell Environ. 2001; 23(5):515-521.

66. Ding XD, Tian CY, Zhang SR, Song J. Effects of $\mathrm{NO}_{3}^{-}-\mathrm{N}$ on the growth and salinity tolerance of Tamarix laxa Plant Soil. 2010;331:57-67.

67. Hameed M, Basra SMA, Ahmad MSA, Naz N. Plant adaptation and phytoremediation. In: Ashraf M (ed) Structural and functional adaptations in plants for salinity tolerance. Springer, Netherlands, 2010.p.151-170.

68. Iqbal N, Umar S, Khan NA. Nitrogen availability regulates proline and ethylene production and alleviates salinity stress in mustard (Brassica juncea). J Plant Physiol. 2015;178:84-91.

69. Ahanger MA, Agarwal RM. Salinity stress induced alterations in antioxidant metabolism and nitrogen assimilation in wheat (Triticum aestivum L) as influenced by potassium supplementation. Plant Physiol Bioch. 2017; 115:449-460.

70. Wang D, Wang H, Han B, Wang B, Guo A, Zheng D, Liu C, Chang L, Peng M, Wang X. Sodium instead of potassium and chloride is an important macronutrient to improve leaf succulence and shoot development for halophyte Sesuvium portulacastrum. Plant Physiol Bioch. 2012; 51:53-62.

71. YU TF, Feng Q, Liu W, Si JH, Xi HY, Chen LJ. Soil water and salinity in response to water deliveries and the relationship with plant growth at the lower reaches of Heihe River, Northwestern China. Acta Ecologica Sinica. 2012; 32:7009-701.

\section{Tables}

Table 1 Distribution of sampling points of different moisture and salinity habitats of Lycium ruthenicum communities in the lower reaches of the Heihe River 


\begin{tabular}{|c|c|c|c|c|c|c|c|c|c|}
\hline No. & Desert types of plots & Longitude & Latitude & $\begin{array}{l}\text { Dominance } \\
\text { index }\end{array}$ & $\begin{array}{l}\text { Evenness } \\
\text { index }\end{array}$ & $\begin{array}{l}\text { 0-40 cm Soil } \\
\text { Moisture } \\
(\%)\end{array}$ & $\begin{array}{l}0-40 \mathrm{~cm} \text { Soil Salinity }\left(\mathrm{g}=\mathrm{kg}^{-}\right. \\
\text {1) }\end{array}$ & $\begin{array}{l}\begin{array}{l}40-80 \mathrm{~cm} \\
\text { Soil }\end{array} \\
\text { Moisture (\%) }\end{array}$ & $\begin{array}{l}40-80 \mathrm{~cm} \text { Soil Salinity ( } g=\mathrm{kg} \\
\text { 1) }\end{array}$ \\
\hline प & Moderately saline Gobi & $101^{\circ} 01^{\prime} 0.6^{\prime \prime}$ & $42^{\circ} 02^{\prime} 9.4^{\prime \prime}$ & $0.70 \pm 0.18 \mathrm{bc}$ & $0.54 \pm 0.28 \mathrm{ab}$ & $1.60 \pm 0.37 \mathrm{~b}$ & $3.09 \pm 0.44 \mathrm{bc}$ & $1.77 \pm 0.24 \mathrm{~d}$ & $0.83 \pm 0.37 \mathrm{c}$ \\
\hline ] & Extremely heavy saline Gobi & $101^{\circ} 01^{\prime} 42.4^{\prime \prime}$ & $42^{\circ} 02^{\prime} 7.8^{\prime \prime}$ & $0.66 \pm 0.24 \mathrm{bcd}$ & $0.55 \pm 0.36 \mathrm{ab}$ & $4.33 \pm 1.61 \mathrm{ab}$ & $12.29 . \pm 1.69 \mathrm{abc}$ & $8.99 \pm 7.12 \mathrm{bcd}$ & $2.67 \pm 1.64 \mathrm{c}$ \\
\hline a & $\begin{array}{l}\text { Extremely heavy saline } \\
\text { desert }\end{array}$ & $101^{\circ} 03^{\prime} 13.9^{\prime \prime}$ & $42^{\circ} 01^{\prime} 28.3^{\prime \prime}$ & $0.51 \pm 0.13 \mathrm{~d}$ & $0.66 \pm 0.13 \mathrm{ab}$ & $10.21 \pm 3.94 \mathrm{a}$ & $13.84 \pm 2.87 \mathrm{abc}$ & $4.45 \pm 1.34 \mathrm{~cd}$ & $1.93 \pm 0.67 \mathrm{c}$ \\
\hline ] & $\begin{array}{l}\text { Extremely heavy saline } \\
\text { desert }\end{array}$ & $101^{\circ} 02^{\prime} 42.0^{\prime \prime}$ & $42^{\circ} 03^{\prime} 11.8^{\prime \prime}$ & $0.86 \pm 0.21 \mathrm{a}$ & $0.27 \pm 0.37 \mathrm{~cd}$ & $14.60 \pm 3.20 \mathrm{a}$ & $11.34 \pm 1.49 \mathrm{abc}$ & $14.15 \pm 1.98 \mathrm{ab}$ & $1.28 \pm 0.26 \mathrm{c}$ \\
\hline a & $\begin{array}{l}\text { Extremely heavy saline } \\
\text { desert }\end{array}$ & $101^{\circ} 02^{\prime} 27.5^{\prime \prime}$ & $42^{\circ} 03^{\prime} 8.0^{\prime \prime}$ & $0.66 \pm 0.14 \mathrm{bcd}$ & $0.69 \pm 0.20 \mathrm{ab}$ & $16.68 \pm 11.4 \mathrm{a}$ & $34.12 \pm 0.76 a$ & $11.04 \pm 4.67 \mathrm{abc}$ & $7.15 \pm 1.16 \mathrm{~b}$ \\
\hline ( & Slightly saline desert & $101^{\circ} 16^{\prime} 59.3^{\prime \prime}$ & $42^{\circ} 02^{\prime} 17.8^{\prime \prime}$ & $0.80 \pm 0.09 \mathrm{ab}$ & $0.51 \pm 0.17 \mathrm{bc}$ & $15.51 \pm 3.85 \mathrm{a}$ & $1.94 \pm 0.35 \mathrm{c}$ & $3.49 \pm 0.14 \mathrm{~cd}$ & $0.69 \pm 0.01 \mathrm{c}$ \\
\hline a & $\begin{array}{l}\text { Extremely heavy saline } \\
\text { desert }\end{array}$ & $101^{\circ} 00^{\prime} 52.5^{\prime \prime}$ & $42^{\circ} 06^{\prime} 56.8^{\prime \prime}$ & $0.94 \pm 0.11 \mathrm{a}$ & $0.16 \pm 0.26 \mathrm{~d}$ & $4.67 \pm 2.23 \mathrm{ab}$ & $27.39 \pm 4.41 \mathrm{ab}$ & $6.46 \pm 3.86 \mathrm{bcd}$ & $2.67 \pm 0.33 \mathrm{c}$ \\
\hline प & $\begin{array}{l}\text { Extremely heavy saline } \\
\text { desert }\end{array}$ & $101^{\circ} 00^{\prime} 3.7^{\prime \prime}$ & $42^{\circ} 06^{\prime} 52.0^{\prime \prime}$ & $0.63 \pm 0.09 \mathrm{~cd}$ & $0.80 \pm 0.15 a$ & $7.96 \pm 4.26 \mathrm{ab}$ & $42.24 \pm 1.01 \mathrm{a}$ & $19 \pm 0.39 a$ & $15.6 \pm 0.80 \mathrm{a}$ \\
\hline
\end{tabular}

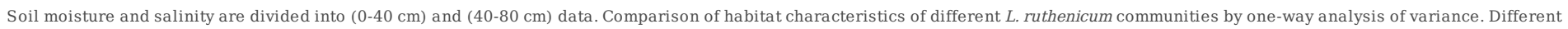

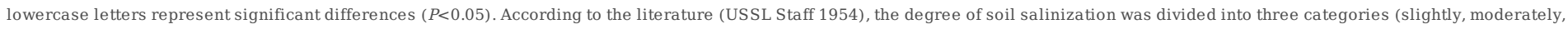
extremely heavy saline).

Table 2 Leaf functional traits of different $L$. ruthenicum communities (Mean $\pm \mathrm{SD}, \mathrm{n}=3$ )

\begin{tabular}{|c|c|c|c|c|c|c|c|c|c|c|c|c|c|c|}
\hline No. & $L T$ & $S L V$ & $S L A$ & $L D M C$ & Suc & $L D$ & $T W C$ & $R W C$ & $C$ & $N$ & $P$ & $N: P$ & $C: N$ & $C: P$ \\
\hline 口 & $1.03 \pm 0.01 \mathrm{c}$ & $6.69 \pm 0.47 \mathrm{bc}$ & $0.007 \pm 0.43 \mathrm{~ns}$ & $141.5 \pm 13.4 \mathrm{ab}$ & $0.83 \pm 0.03 \mathrm{~b}$ & $0.15 \pm 0.01 \mathrm{ab}$ & $83.15 \pm 0.01 \mathrm{~cd}$ & $81.32 \pm 0.01 b$ & $347.5 \pm 0.42 \mathrm{a}$ & $13.57 \pm 0.06 \mathrm{c}$ & $3.98 \pm 0.16 b$ & $3.42 \pm 0.16 \mathrm{~b}$ & $25.79 \pm 0.42 \mathrm{c}$ & $84.97 \pm 4.0$ \\
\hline ㅁ. & $1.14 \pm 0.10 \mathrm{bc}$ & $7.00 \pm 0.67 \mathrm{bc}$ & $0.006 \pm 0.47 \mathrm{~ns}$ & $147.5 \pm 5.1 \mathrm{ab}$ & $0.99 \pm 0.04 \mathrm{ab}$ & $0.14 \pm 0.01 \mathrm{ab}$ & $82.0 \pm 0.01 \mathrm{~cd}$ & $78.85 \pm 0.03 c$ & $337.8 \pm 0.29 \mathrm{a}$ & $14.84 \pm 0.43 \mathrm{~b}$ & $3.09 \pm 0.00 \mathrm{~b}$ & $4.80 \pm 0.14 \mathrm{ab}$ & $23.34 \pm 0.89 \mathrm{~d}$ & $107.48 \pm 2$ \\
\hline a & $1.26 \pm 0.00 \mathrm{abc}$ & $8.40 \pm 1.40 \mathrm{abc}$ & $0.006 \pm 1.11 \mathrm{~ns}$ & $144.7 \pm 11.3 \mathrm{ab}$ & $0.89 \pm 0.07 \mathrm{~b}$ & $0.12 \pm 0.02 \mathrm{bc}$ & $82.26 \pm 0.01 \mathrm{~cd}$ & $78.46 \pm 0.02 \mathrm{c}$ & $342.4 \pm 0.29 \mathrm{a}$ & $16.92 \pm 0.89 a$ & $1.53 \pm 0.91 \mathrm{c}$ & $17.70 \pm 11.13 \mathrm{a}$ & $20.28 \pm 0.74 \mathrm{e}$ & $435.75 \pm 25$ \\
\hline a & $1.36 \pm 0.01 \mathrm{ab}$ & $7.81 \pm 0.19 \mathrm{abc}$ & $0.005 \pm 0.10 \mathrm{~ns}$ & $125.0 \pm 1.7 \mathrm{abc}$ & $1.03 \pm 0.03 \mathrm{ab}$ & $0.13 \pm 0.00 \mathrm{bc}$ & $83.13 \pm 0.00 \mathrm{~cd}$ & $70.41 \pm 0.00 \mathrm{c}$ & $324.1 \pm 0.12 b$ & $13.04 \pm 0.04 \mathrm{c}$ & $1.01 \pm 0.14 \mathrm{c}$ & $13.16 \pm 1.76 \mathrm{ab}$ & $26.16 \pm 1.85 \mathrm{c}$ & $335.3 \pm 11$. \\
\hline 口 & $1.26 \pm 0.23 \mathrm{abc}$ & $5.74 \pm 0.38 \mathrm{c}$ & $0.005 \pm 0.54 \mathrm{~ns}$ & $197.9 \pm 21.0 \mathrm{a}$ & $0.90 \pm 0.04 \mathrm{~b}$ & $0.17 \pm 0.01 \mathrm{a}$ & $79.35 \pm 0.02 \mathrm{~d}$ & $94.81 \pm 0.00 \mathrm{c}$ & $337.6 \pm 0.16 \mathrm{a}$ & $9.93 \pm 0.04 \mathrm{~d}$ & $0.81 \pm 0.00 \mathrm{c}$ & $12.22 \pm 0.00 \mathrm{ab}$ & $34.34 \pm 0.48 b$ & $414.1 \pm 1.8$ \\
\hline 口 & $1.24 \pm 0.02 \mathrm{bc}$ & $7.38 \pm 0.13 \mathrm{bc}$ & $0.007 \pm 0.12 \mathrm{~ns}$ & $137.9 \pm 2.2 \mathrm{abc}$ & $0.87 \pm 0.03 \mathrm{~b}$ & $0.14 \pm 0.00 \mathrm{abc}$ & $84.91 \pm 0.00 \mathrm{bc}$ & $90.0 \pm 0.00 \mathrm{c}$ & $341.3 \pm 0.04 \mathrm{a}$ & $15.07 \pm 0.27 \mathrm{~b}$ & $1.54 \pm 0.11 \mathrm{c}$ & $9.87 \pm 0.90 \mathrm{ab}$ & $22.66 \pm 0.35 d$ & $223.3 \pm 13$ \\
\hline a & $1.58 \pm 0.05 a$ & $9.14 \pm 0.64 \mathrm{ab}$ & $0.006 \pm 0.24 \mathrm{~ns}$ & $153.1 \pm 7.5 b c$ & $1.24 \pm 0.14 \mathrm{a}$ & $0.11 \pm 0.01 \mathrm{bc}$ & $88.37 \pm 0.01 \mathrm{ab}$ & $137.35 \pm 0.02 \mathrm{a}$ & $308.6 \pm 0.12 \mathrm{c}$ & $15.15 \pm 0.17 b$ & $5.45 \pm 0.32 \mathrm{a}$ & $2.79 \pm 0.20 \mathrm{~b}$ & $20.56 \pm 0.30 \mathrm{e}$ & $58.05 \pm 1.1$ \\
\hline ㅁ & $1.37 \pm 0.01 \mathrm{ab}$ & $10.90 \pm 1.90 \mathrm{a}$ & $0.008 \pm 1.48 \mathrm{~ns}$ & $151.5 \pm 8.5 \mathrm{c}$ & $1.03 \pm 0.10 \mathrm{ab}$ & $0.09 \pm 0.02 \mathrm{c}$ & $87.95 \pm 0.01 \mathrm{a}$ & $130.36 \pm 0.01 \mathrm{~b}$ & $319.9 \pm 0.54 \mathrm{~b}$ & $8.43 \pm 0.34 \mathrm{e}$ & $2.87 \pm 0.00 \mathrm{~b}$ & $2.94 \pm 0.12 \mathrm{~b}$ & $38.54 \pm 1.07 \mathrm{a}$ & $112.3 \pm 0.7$ \\
\hline
\end{tabular}

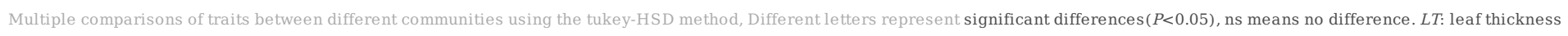

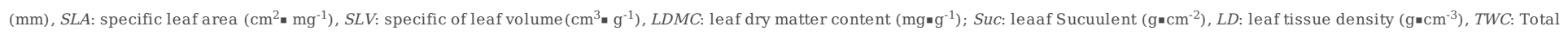

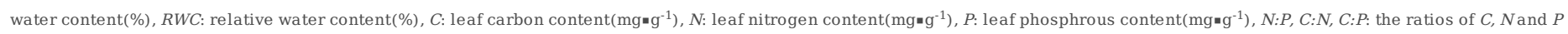

Table 3 Ordination of the 14 functional traits, according to two depths of soil moistures, salinity and eight ions, along the first two axes of a redundancy analysis 


\begin{tabular}{|c|c|c|c|c|c|c|}
\hline \multirow[t]{2}{*}{ Parameters } & \multicolumn{4}{|c|}{ Explanation \% } & \multirow[t]{2}{*}{$\mathrm{F}$} & \multirow[t]{2}{*}{$P$} \\
\hline & Axis1 & Axis 2 & Axis3 & Axis4 & & \\
\hline \multicolumn{7}{|l|}{$0-40 \mathrm{~cm}$ soil ions, salinity and water content } \\
\hline $\mathrm{SO}_{4}{ }^{2-}$ & & 5.7 & & & 0.84 & 0.40 \\
\hline $\mathrm{Cl}^{-1}$ & & 14.8 & & & 2.43 & 0.14 \\
\hline $\mathrm{CO}_{3}{ }^{2-}$ & & 16.0 & & & 2.7 & 0.13 \\
\hline $\mathrm{HCO}_{3}^{-}$ & & 16.4 & & & 2.76 & 0.11 \\
\hline $\mathrm{Ca}^{2+}$ & & 3.6 & & & 0.53 & 0.50 \\
\hline $\mathrm{Mg}^{2+}$ & & 4.8 & & & 0.70 & 0.43 \\
\hline $\mathrm{Na}^{+}$ & & 6.6 & & & 0.99 & 0.35 \\
\hline $\mathrm{K}^{+}$ & & 19.1 & & & 3.30 & 0.082 \\
\hline Salinity & & 6.8 & & & 1.03 & 0.276 \\
\hline Soil water content & & 62.5 & & & 23.35 & $0.002 * *$ \\
\hline Eigen & 0.86 & 0.10 & 0.03 & 0.01 & & \\
\hline Explained variation (cumulative) & 93.27 & 93.45 & 93.47 & 93.48 & & \\
\hline Pseudo-canonical correlation & 1 & 1 & 1 & 1 & & \\
\hline Permutation Test Results: First Axis & & & & & 6.9 & $0.002 * *$ \\
\hline All Axes & & & & & 11429 & $0.002 * *$ \\
\hline \multicolumn{7}{|l|}{$40-80 \mathrm{~cm}$ soil ions, salinity and water content } \\
\hline $\mathrm{SO}_{4}{ }^{2-}$ & & 12.5 & & & 2.00 & 0.2 \\
\hline $\mathrm{Cl}^{-1}$ & & 13.6 & & & 2.21 & 0.17 \\
\hline $\mathrm{CO}_{3}{ }^{2-}$ & & 5.4 & & & 0.79 & 0.38 \\
\hline $\mathrm{HCO}_{3}^{-}$ & & 40 & & & 9.35 & $0.004 * *$ \\
\hline $\mathrm{Ca}^{2+}$ & & 8.9 & & & 1.37 & 0.25 \\
\hline $\mathrm{Mg}^{2+}$ & & 9.5 & & & 1.48 & 0.25 \\
\hline $\mathrm{Na}^{+}$ & & 11 & & & 1.74 & 0.21 \\
\hline $\mathrm{K}^{+}$ & & 3.8 & & & 0.56 & 0.49 \\
\hline Salinity & & 10.1 & & & 1.57 & 0.23 \\
\hline soil water content & & 6.4 & & & 0.96 & 0.36 \\
\hline Eigen & 0.99 & 0.00 & 0.00 & 0.00 & & \\
\hline Explained variation (cumulative) & 99.69 & 99.96 & 99.98 & 100 & & \\
\hline Pseudo-canonical correlation & 1 & 1 & 1 & 1 & & \\
\hline Permutation Test Results: First Axis & & & & & 365 & $0.002 * *$ \\
\hline All Axes & & & & & 11429 & $0.002 * *$ \\
\hline
\end{tabular}

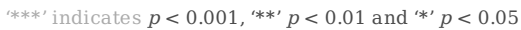

\section{Additional File}

Additional file 1. Raw data of environmental variables included $0-40 \mathrm{~cm}$ and $40-80 \mathrm{~cm}$ soil ions $\left(\mathrm{Na}^{+}, \mathrm{K}^{+}, \mathrm{Ca}^{2+}, \mathrm{Mg}^{2+}\right.$ and $\left.\mathrm{SO}_{4}{ }^{2-}, \mathrm{CO}_{3}{ }^{2-}, \mathrm{HCO}_{3}{ }^{-}, \mathrm{Cl}^{-}\right)$in the lower reaches of Heihe River, Northwest China.

\section{Figures}

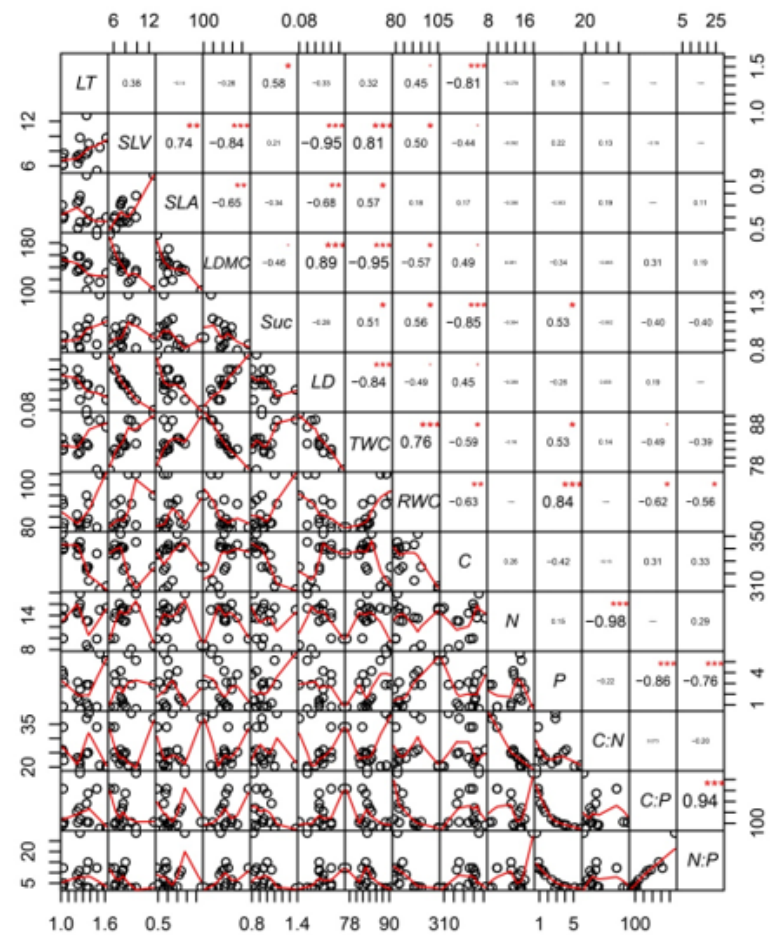




\section{Figure 1}

Correlation analysis among leaf functional traits. Drawing using R software 'PerformanceAnalytics' package, the numbers in the upper triangular region of the graph indicate correlation coefficients, and the asterisks indicate significance, the lower triangle is a linear regression between the two traits. LT: leaf thickness $(\mathrm{mm}), \mathrm{SLA}$ : specific leaf area (cm2 mg-1), SLV: specific of leaf volume (cm3 $\mathrm{g}-1)$, LDMC: leaf dry matter content (mg-g-1); Suc: leaaf Sucuulent (g-cm-2), LD: leaf tissue density ( $\mathrm{g}=\mathrm{cm}-3)$, TWC: Total water content (\%), RWC: relative water content (\%), C: leaf carbon content (mg $\mathrm{m}-1)$, N: leaf nitrogen content

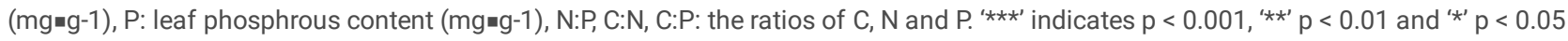
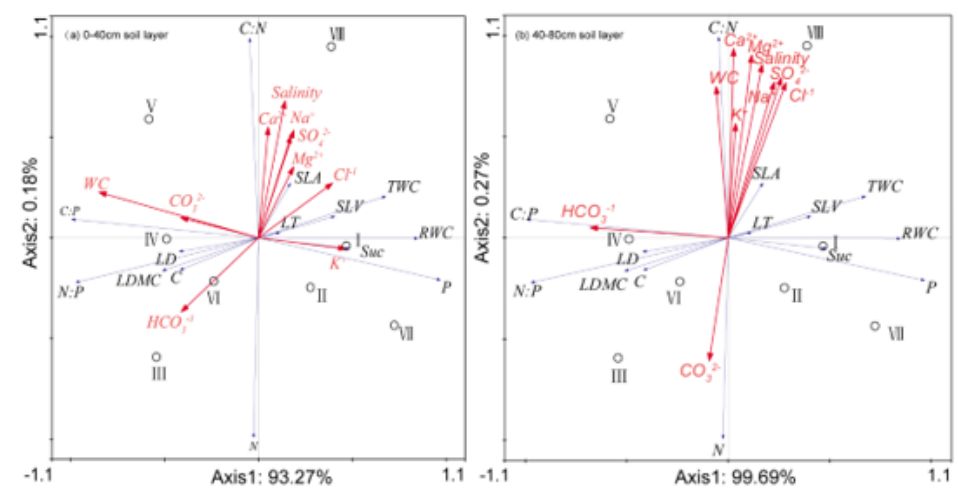

\section{Figure 2}

RDA ordination graph of leaf functional traits and environmental variables of the L. ruthenicum communities in the lower reaches of the Heihe River. The direction of the arrow indicating a positive or negative correlation among the environmental factors with the ordination axes. The angle of the arrow reflects the strength of correlation between the environmental factors and functional traits, with small angles indicating strong correlations, large angle opposite. Environmental variables included 0-40 cm and 40-80 cm soil salinity, soil water content (WC) and eight soil ions ( $\mathrm{Na}+, \mathrm{K}+, \mathrm{Ca} 2+, \mathrm{Mg} 2+$ and $\mathrm{SO} 42-, \mathrm{CO} 32-$, $\mathrm{HCO}-, \mathrm{Cl}-$ )

\section{Supplementary Files}

This is a list of supplementary files associated with this preprint. Click to download.

- supplement1.xlsx 